\title{
The essential oil of Hyptis crenata Pohl ex Benth. presents an antiedematogenic effect in mice
}

\author{
A.N. Coelho-de-Souza ${ }^{1 \oplus}$, R. Alves-Soares ${ }^{1 \oplus}$, H.D. Oliveira ${ }^{2 \oplus}$, Y.A. Gomes-Vasconcelos $^{1 \oplus}$, \\ P.J.C. Souza ${ }^{3 \oplus}$, T. Santos-Nascimento ${ }^{4 \oplus}$, K.A. Oliveira ${ }^{1 \oplus}$, L.R.L. Diniz ${ }^{5 \oplus}$, J. Guimarães-Pereira ${ }^{1 \oplus}$, \\ and J.H. Leal-Cardoso \\ ${ }^{1}$ Laboratório de Fisiologia Experimental, Instituto Superior de Ciências Biomédicas, Universidade Estadual do Ceará, \\ Campus do Itaperi, Fortaleza, CE, Brasil \\ ${ }^{2}$ Programa de Pós-Graduação em Bioquímica, Universidade Federal do Ceará, Fortaleza, CE, Brasil \\ ${ }^{3}$ Departamento de Farmácia, Universidade Federal do Pará, Belém, PA, Brasil \\ ${ }^{4}$ Faculdade do Vale do Jaguaribe, Fortaleza, CE, Brasil \\ ${ }^{5}$ Faculdade do Nordeste da Bahia, Salvador, BA, Brasil \\ ${ }^{6}$ Laboratório de Eletrofisiologia, Instituto Superior de Ciências Biomédicas, Universidade Estadual do Ceará, \\ Campus do Itaperi, Fortaleza, CE, Brasil
}

\begin{abstract}
Hyptis crenata, commonly known as "salva-do-Marajó", "hortelã-do-campo", and "hortelãzinha", is used in folk medicine in Northeast Brazil as tea or infusion to treat inflammatory diseases. Due to the pharmacological efficacy and the low toxicity of the essential oil of Hyptis crenata $(\mathrm{EOHc})$, we decided to investigate the EOHc antiedematogenic effect in experimental models of inflammation. EOHc was administrated orally at doses of 10-300 mg/kg to male Swiss albino mice. Paw edema was induced by subcutaneous injection in the right hind paw of inflammatory stimuli (carrageenan, dextran, histamine, serotonin, and bradykinin) $60 \mathrm{~min}$ after administration of EOHc. EOHc significantly inhibited the induced edema. The inhibitory effect of EOHc on dextran-induced edema extended throughout the experimental time. For the 30, 100, and $300 \mathrm{mg} / \mathrm{kg} \mathrm{doses}$ of EOHc, the inhibition was of $40.28 \pm 1.70,51.18 \pm 2.69$, and $59.24 \pm 2.13 \%$, respectively. The EOHc inhibitory effect on carrageenan-induced edema started at $10 \mathrm{mg} / \mathrm{kg}$ at the second hour (h) and was maintained throughout the observation period. At 30,100 , and $300 \mathrm{mg} / \mathrm{kg}$ doses the inhibition started earlier, from $30 \mathrm{~min}$. At the edema peak of $180 \mathrm{~min}, 56,76$, and $82 \%$ inhibition was observed for 30,100 , and $300 \mathrm{mg} / \mathrm{kg}$ doses, respectively. Additionally, the effect of EOHc on carrageenaninduced paw edema was influenced by the time of administration. The EOHc also inhibited myeloperoxidase activity. In conclusion, the EOHc showed a potent effect, both preventing and reversing the edema, consistent with its anti-inflammatory use in folk medicine.
\end{abstract}

Key words: Medicinal plants; Essential oil; Hyptis crenata; Antiedematogenic activity; Inflammation

\section{Introduction}

Plants of the Hyptis genus belong to the Lamiaceae family, which ranks third in ethnopharmacological importance $(1,2)$. In Brazil, Hyptis plants occur in several states of the North, Northeast (3), Midwest, and Southeast regions, usually in the Amazon rainforest (4) and Cerrado (1) where they are used for different purposes, ranging from appetizer, food flavoring, and bath aromatization, to treatment of various diseases including inflammation $(5,6)$, respiratory $(7)$ and gastrointestinal disorders $(3,6,8)$, constipation, and arthritis $(7,9)$. In the Brazilian Northeast, $H$. crenata is used in folk medicine in the form of tea or infusion. H. crenata, commonly known as "salva-do-Marajó", "hortelã-do-campo", and "hortelãzinha", is rich in essential oils (EO), which main constituents are camphor, 1.8-cineole, and alpha-pinene $(10,11)$.

Some biological activities of $H$. crenata, such as antimicrobial (12), bactericidal, larvicide (13), antioxidant (5), gastroprotective (8), and hepatoprotective (14), are already documented. Recent studies from our research group have shown that the essential oil of Hyptis crenata $(\mathrm{EOHc})$ has low acute toxicity by the oral route (10). It demonstrated a hepatoprotective effect in sepsis-induced liver dysfunction at $100 \mathrm{mg} / \mathrm{kg}$ (po) during 14 days (14). EOHc has also shown a 
gastroprotective action (8), which was attributed to $\alpha$-pinene, one of its major constituents (3). The low acute toxicity of $\mathrm{EOHc}$ was demonstrated through the value of its median lethal dose $\left(L D_{50}\right)$ that was estimated to be greater than $2000 \mathrm{mg} / \mathrm{kg}(10)$.

The EOHc has demonstrated pharmacological efficacy and low toxicity, it is abundant in plant parts, and its use is common in folk medicine to treat swelling and inflammation of the limbs. Thus, we aimed to investigate the $\mathrm{EOHc}$ antiedematogenic effect.

\section{Material and Methods}

\section{Essential oil extraction}

The EOHc was obtained from leaves and branches of $H$. crenata by steam distillation (Detiller MA480, Marco$\mathrm{ni}^{\mathrm{R}}$, Brazil) as described for other essential oils (8,14-18). The plant was collected (January 2011) in the city of São Raimundo das Mangabeiras, Maranhão State, Brazil $\left(7^{\circ} 1^{\prime} 19^{\prime \prime} \mathrm{S}, 45^{\circ} 28^{\prime} 51^{\prime \prime} \mathrm{W}\right)$. The identification was confirmed by Dr. Oriel Herera Bonilla (Ecology Laboratory, Brazil) and a voucher sample (No. 000106) was deposited at the Marlene Freitas da Silva herbarium (Brazil). Chemical constituents of the EOHc were kindly determined by Dr. Afrânio Aragão Craveiro from Technological Development Park of the Federal University of Ceará (PADETEC/UFC), by gas chromatography coupled to mass spectrometry (GC-MS, Hewlett-Packard 6971, USA). Analysis conditions were as follows: column of dimethylpolysiloxane DB-1 fused silica capillary column (30 $\mathrm{m} \times 0.25 \mathrm{~mm} ; 0.1 \mu \mathrm{m})$; helium $(1 \mathrm{~mL} / \mathrm{min})$ as carrier gas; injector temperature: $250^{\circ} \mathrm{C}$; detector temperature: $200^{\circ} \mathrm{C}$; column temperature: $35-180^{\circ} \mathrm{C}$ at $4^{\circ} \mathrm{C} / \mathrm{min}$ and $180-250^{\circ} \mathrm{C}$ at $10^{\circ} \mathrm{C} / \mathrm{min}$; and mass spectra: electronic impact $70 \mathrm{eV}$. The compounds were identified (Figure 1 and Table 1) using mass spectral library search.

\section{Drugs and solutions}

All salts and drugs used were of analytical purity. Carrageenan, dextran, indomethacin, histamine, serotonin, bradykinin, hexadecyltrimethylammonium bromide (CTAB), o-dianisidine dihydrochloride, hydrogen peroxide, and cyproheptadine were acquired from Sigma-Aldrich Chemical Corporation (USA). Tween 80 and $\mathrm{NaCl}$ were from Reagem (Brazil). Solutions were prepared by adding pure substance to sterile saline $(0.9 \% \mathrm{NaCl})$. $\mathrm{EOHc}$ was prepared in sterile saline, containing Tween $80,0.1 \% \mathrm{v} / \mathrm{v}$, followed by automatic stirring. After homogenization, the solution was administered by the orogastric route.

\section{Animals}

Male Swiss albino (Mus musculus) mice (30-40 g) were obtained from Christus University Center (UNICHRISTUS) vivarium and kept at the vivarium of the State University of Ceará (UECE) in a box of polypropylene, at a temperature of $23 \pm 2^{\circ} \mathrm{C}, 12 \mathrm{~h}$ dark/light cycle, and free access to water and food. The experimental protocol was approved by the Committee on Ethics in the Use of Animals of the State University of Ceará (CEUA/ UECE; protocol number 2960651/2015) and followed the ethical principles on manipulation and use of laboratory animals of the Brazilian Society of Science in Laboratory Animals.

\section{Paw edema induction}

Paw edema was induced by intra-plantar subcutaneous injection in the right hind paw of $50 \mu \mathrm{L}$ of the inflammatory stimuli carrageenan or dextran (both at $1 \%$ ), histamine $(50 \mathrm{nmol} / \mathrm{paw})$, serotonin $(1 \mu \mathrm{g} / \mathrm{paw})$, or bradykinin (3 nmol/paw), 60 min after intragastric administration of $\mathrm{EOHc}$, indomethacin $(10 \mathrm{mg} / \mathrm{kg}$ ), cyproheptadine (5 or $10 \mathrm{mg} / \mathrm{kg}$ ), or $\mathrm{EOHc}$ vehicle (Tween $80,0.05 \% \mathrm{v} / \mathrm{v}$ ). For blockade of carrageenan- or dextran-induced edema, the

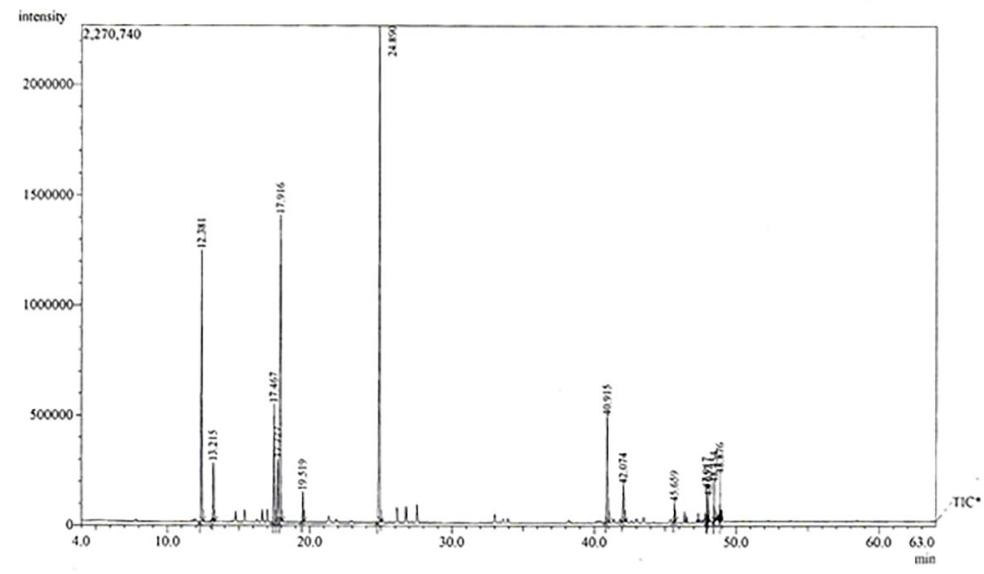

Figure 1. Gas chromatogram (GC-MS) of essential oil of leaves of Hyptis crenata. The peaks correspond to the retention time for the constituents identified. 
Table 1. Chemical composition of the essential oil of Hyptis crenata (EOHc), based on retention time.

\begin{tabular}{lccc}
\hline Peak & Compound & Retention time & Area (\%) \\
\hline 1 & $\alpha$-pinene & 12.381 & $15.24^{*}$ \\
2 & Camphene & 13.215 & 3.23 \\
3 & $\rho$-cymene & 17.467 & 6.85 \\
4 & I-Limonene & 17.727 & 3.94 \\
5 & 1.8-cineole (Eucalyptol) & 17.916 & $19.76^{*}$ \\
6 & $\gamma$-terpinene & 19.519 & 1.73 \\
7 & Camphor & 24.890 & $33.62^{*}$ \\
8 & $\beta$-caryophyllene & 40.915 & $8.00^{*}$ \\
9 & Aromadendrene & 42.074 & 2.95 \\
10 & Ledene & 45.659 & 0.99 \\
11 & Caryophyllene oxide & 47.917 & 0.84 \\
12 & Viridiflorol & 48.052 & 0.85 \\
13 & 10-epi- $\gamma$-eudesmole & 48.454 & 0.96 \\
14 & Caryophyllene oxide & 48.876 & 1.05 \\
Total & & & 100.00 \\
\hline
\end{tabular}

*Main compounds identified using mass spectral library search.

EOHc was administered at the doses of $10,30,100$, or $300 \mathrm{mg} / \mathrm{kg}$; for inhibition of response to other inflammatory stimuli histamine (HA), serotonin $(5-\mathrm{HT})$ or bradykinin (BK), the essential oil was used at the dose of 100 and $300 \mathrm{mg} / \mathrm{kg}$, which represents less than $15 \%$ of the $\mathrm{LD}_{50}$. The contralateral paw (control) received, subcutaneously, an equal volume of $0.9 \% \mathrm{NaCl}$ (the vehicle of dextran or carrageenan). Paw volume variation was measured with a plethysmometer (Panlab, S.L.U., Digital Water Plethysmometer Le 7500, USA) before (zero time), at the 30th and 60th $\mathrm{min}$, and afterwards, every $60 \mathrm{~min}$ up to $240 \mathrm{~min}$ (for dextran), or up to $300 \mathrm{~min}$ (for carrageenan). Edema was considered to be the difference in paw volume measured at different time periods and time zero. In this study, the time course of carrageenan-induced paw edema was considered to have three phases, as in another study (15): a first phase, occurring in the first 60 min after drug administration, resulting of the presence of histamine and serotonin; a second phase, from (61-120 min), named osmotic phase, thought to involve the kinin system (19); and a third phase, from (121-180 $\mathrm{min}$ ), named cellular phase, triggered by different mediators, including prostaglandins or a mix of prostaglandins and slow-reacting substances.

To determine whether the time of administration would influence the effect of EOHc on carrageenan-induced edema, in another experimental series, EOHc $(100 \mathrm{mg} / \mathrm{kg})$ or vehicle was administered 60 and 30 min before, at the time of induction, or $30 \mathrm{~min}$ after edema induction. The paw edema was evaluated at 30, 60, 120, 180, 240, 300, 1440 (24 h), and 2880 (48 h) min after edema induction.

\section{Myeloperoxidase (MPO) activity}

For MPO activity, paw edema was induced by intraplantar injection in the right hind paw of $50 \mu \mathrm{L}$ of inflammatory stimuli, carrageenan at $1 \%, 60 \mathrm{~min}$ after intra-gastric administration of EOHc $(100 \mathrm{mg} / \mathrm{kg}$ ) or vehicle (Tween 80 , $0.05 \% \mathrm{v} / \mathrm{v}$ ). The contralateral paw (control) received an equal volume of $0.9 \% \mathrm{NaCl}$. At the inflammatory peak, $180 \mathrm{~min}$ after edema induction, the animals were sacrificed, subplantar tissue was removed, and immediately processed for analysis of MPO activity according to the method described by Rao et al. (20). The MPO assay reaction mixture consisted of the supernatant, $0.5 \%$ hexadecyltrimethylammonium bromide (CTAB), $0.68 \mathrm{mg} / \mathrm{mL}$ o-dianisidine dihydrochloride, and $0.003 \%$ hydrogen peroxide. The absorbance of this mixture was measured at $450 \mathrm{~nm}$. One unit of MPO activity was defined as the quantity of enzyme degrading $1.0 \mu \mathrm{mol}$ of hydrogen peroxide per $\min$ at $25^{\circ} \mathrm{C}$, reported as MPO $\times 10^{3} \mathrm{U} / \mathrm{mg}$ tissue.

\section{Statistical analysis}

Data are reported as means \pm SE. The graph and the statistical analysis were done with the software Sigmaplot ${ }^{\mathbb{R}}$ (version 11.0, Systat Software, USA). Twoway analysis of variance (ANOVA) was used to compare the means followed by Bonferroni test, a multiple comparison method. For area under curve (AUC) and myeloperoxidase activity graphics, we used one-way ANOVA, followed by Bonferroni test. Results showing a probability of occurrence of the null hypothesis less than $5 \%$ $(P<0.05)$ were considered statistically different.

\section{Results}

\section{Main constituents of EOHc}

Figure 1 shows the chromatogram for analysis of the EOHc by GC-MS. As can be seen, four main peaks were identified, which correspond to the major constituents 


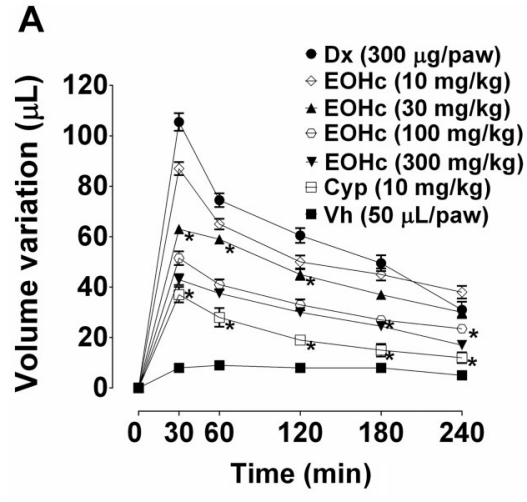

B

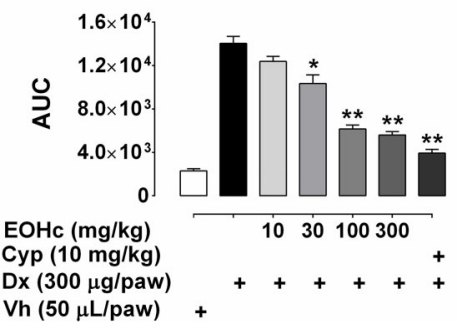

Figure 2. Effect of essential oil of Hyptys crenata $(\mathrm{EOHc})$ on paw edema induced by dextran. $\mathbf{A}$ and $\mathbf{B}$, Effect of several doses of EOHc $(10-300 \mathrm{mg} / \mathrm{kg}$, orally) and of cyproheptadine (Cyp, $10 \mathrm{mg} / \mathrm{kg}$ ) on the time course (30-240 min) of edema induced by intraplantar injection of dextran (Dx, $300 \mu \mathrm{g} / \mathrm{paw}$ ) or Vehicle ( $\mathrm{Vh}, 0.9 \% \mathrm{NaCl}$ solution, $50 \mu \mathrm{L} / \mathrm{paw}$ ). Data are reported as means $\pm \mathrm{SE}$ ( $\mathrm{n}=10$ ). ${ }^{*} \mathrm{P}<0.05,{ }^{* *} \mathrm{P}<0.01$ vs control (two-way ANOVA followed by Bonferroni's test).

camphor (33.62), 1.8-cineole also known as eucalyptol (19.76\%), $\alpha$-pinene (15.24\%), and $\beta$-caryophyllene (8.00\%), followed by 10 smaller peaks. By analyzing the retention time, $100 \%$ of the constituents were identified (Table 1).

\section{Inhibition of dextran-induced edema}

EOHc significantly inhibited dextran-induced edema (Figure 2A and B). The inhibitory effect of EOHc extended throughout the experimental time $(240 \mathrm{~min})$ for doses $\geqslant$ $100 \mathrm{mg} / \mathrm{kg}$. For the doses of 30,100 , and $300 \mathrm{mg} / \mathrm{kg}$ of $\mathrm{EOHc}$, the observed inhibition corresponded to $40.28 \pm$ $1.70,51.18 \pm 2.69$, and $59.24 \pm 2.13 \%$, respectively, of control (105.5 $\pm 3.45 \mu \mathrm{L}$ of paw volume variation) edema.

\section{Inhibition of carrageenan-induced edema}

EOHc also had an inhibitory effect on edema induced by carrageenan (Figure $3 \mathrm{~A}$ and $\mathrm{B}$ ). For the dose of $10 \mathrm{mg} / \mathrm{kg}$, this effect started from the $2 \mathrm{nd} \mathrm{h}$ and was maintained throughout of the observation period. At the doses of 30,100 , and $300 \mathrm{mg} / \mathrm{kg}$ the inhibition started earlier, from $30 \mathrm{~min}$. At the edema peak, $180 \mathrm{~min}$, the paw volume inhibition corresponded to 56,76 , and $82 \%$ of the paw volume increase by carrageenan $(130 \pm 5.1099 \mu \mathrm{L})$ for doses of 30,100 , and $300 \mathrm{mg} / \mathrm{kg}$, respectively. Indomethacin (positive control) inhibited $84.5 \%$ of peak control edema.

\section{Influence of time of EOHc administration on carrageenan-induced paw edema}

For this experimental series, the dose of $100 \mathrm{mg} / \mathrm{kg}$ of $\mathrm{EOHc}$ was used, because this was the lowest dose that had a similar effect to indomethacin, the positive control. In this way, any possible adverse effect would be minimized. The observation period was extended to $48 \mathrm{~h}$ after edema induction. Administered at different times relative to the time of administration of the edema inducing agent, the best EOHc effect occurred when EOHc was administered 60 min prior to the carrageenan (Figure 3D). Surprisingly, the effect of the EOHc lasted $48 \mathrm{~h}$. Comparing the area under the curve for the inhibitory effect of $\mathrm{EOHc}(100 \mathrm{mg} / \mathrm{kg})$, it can be seen that when administered $1 \mathrm{~h}$ before edema induction the inhibition corresponded to $65.71 \%$ of control (Figure $3 \mathrm{C}$ and D). For administration at $1 \mathrm{~h}$ before edema induction, the inhibitory effect was similar at all times of observation, 30,60, 120, 240, 360, $1440 \mathrm{~min}(24 \mathrm{~h})$, and $2880 \mathrm{~min}$ (48 h) (Figure $3 \mathrm{C})$.

\section{Inhibition of paw edema induced by the autacoids histamine, serotonin, and bradykinin}

For this experimental series, the $\mathrm{EOHc}$ was used at the doses of $100 \mathrm{mg} / \mathrm{kg}$ and $300 \mathrm{mg} / \mathrm{kg}$, which significantly inhibited histamine-, serotonin-, and bradykinin-induced edema (Figure 4, panels A-F).

Concerning the edema induced by histamine, the EOHc (100 and $300 \mathrm{mg} / \mathrm{kg}$ ) inhibitory effect extended over the first 60 min (Figure 4A and D). At the peak of histamine-induced edematogenic effect, which occurred at $15 \mathrm{~min}$ (Figure 4A), 100 and $300 \mathrm{mg} / \mathrm{kg} \mathrm{EOHc}$ inhibited $42.88 \pm 3.36$ and $48.69 \pm 2.81 \%$, respectively, of the histamine-induced paw volume increase (103.3 \pm $3.606 \mu \mathrm{L}$ ). The cyproheptadine (positive control) inhibited $59.12 \pm 6.20 \%$ of peak histamine-induced edema (Figure 4A).

In relation to edema induced by serotonin (Figure 4B and $E$ ), the inhibitory effect of EOHc (100 and $300 \mathrm{mg} / \mathrm{kg}$ ) also started in the first $15 \mathrm{~min}$ after serotonin administration and was maintained throughout the observation period (120 min). At the edema peak (15 min after serotonin administration), paw volume inhibition corresponded to $22.95 \pm 5.17$ and $37.25 \pm 5.57 \%$ (for EOHc 100 and $300 \mathrm{mg} / \mathrm{kg}$, respectively) of the paw volume increase by serotonin $(181.7 \pm 7.05 \mu \mathrm{L})$. The positive 

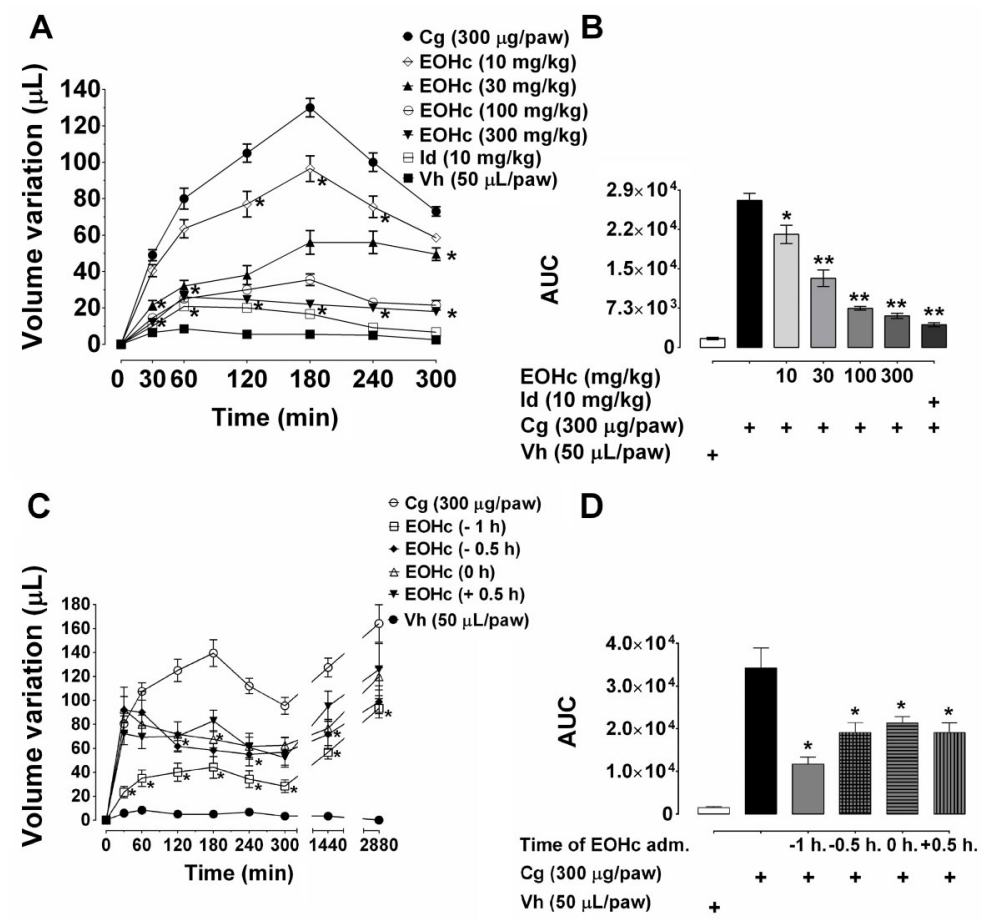

Figure 3. Effect of essential oil of Hyptys crenata $(\mathrm{EOHc})$ on paw edema induced by carrageenan. $\mathbf{A}$ and $\mathbf{B}$, Effect of several doses of EOHc (10-300 mg/kg, orally) and of indomethacin (ld, $10 \mathrm{mg} / \mathrm{kg}$ ) on the time course (30-300 min) of edema induced by intraplantar injection of carrageenan $(\mathrm{Cg}, 300 \mu \mathrm{g} / \mathrm{paw})$ or of its vehicle $(\mathrm{Vh}, 0.9 \% \mathrm{NaCl}$ solution, $50 \mu \mathrm{L} / \mathrm{paw})$. C and $\mathbf{D}$, Influence of time of administration on the anti-inflammatory effect of EOHc $(100 \mathrm{mg} / \mathrm{kg})$ on the time course (30 min up to $48 \mathrm{~h})$ of carrageenan-induced edema. The negative numbers $(-1$ and $-0.5 \mathrm{~h})$ indicate administration of EOHc before edema induction, the positive number $(+0.5 \mathrm{~h})$ indicates administration of $\mathrm{EOHc}$ after edema induction and $\mathrm{O} \mathrm{h}$ indicates administration of $\mathrm{EOHc}$ concomitant with edema induction. ${ }^{*} \mathrm{P}<0.05,{ }^{* *} \mathrm{P}<0.01$ vs control (two-way ANOVA followed by Bonferroni's test).

control (cyproheptadine) inhibited $74.95 \pm 3.16 \%$ of peak control edema (Figure 4B).

EOHc (100 and $300 \mathrm{mg} / \mathrm{kg}$ ) had inhibitory effect on edema induced by bradykinin (Figure $4 \mathrm{C}$ and $\mathrm{F}$ ) observed at 10,20 , and $30 \mathrm{~min}$ after injection of bradykinin. At the peak of edema, at the 20th min after bradykinin administration, the inhibition of paw volume corresponded to $57.34 \pm 6.54$ and $61.1 \pm 4.13 \%$ (EOHc 100 and $300 \mathrm{mg} / \mathrm{kg}$, respectively) of the increase in paw volume by bradykinin $(100.8 \pm 5.43 \mu \mathrm{L})$.

Comparing the area under the curve for the inhibitory effect of 100 and $300 \mathrm{mg} / \mathrm{kg} \mathrm{EOHc}$, the inhibition induced by these doses was, respectively, $34.51 \pm 5.19$ and $40.37 \pm$ $3.58 \%$ for histamine (Figure 4D), $34.42 \pm 6.69$ and $44.49 \pm$ $4.76 \%$ for serotonin (Figure 4E), and $43.66 \pm 12.74$ and $52.51 \pm 1.87 \%$ for bradykinin effect (Figure 4F).

\section{Effect of EOHc on MPO activity}

As expected, at the inflammatory peak, 180 min after edema induction, the paw edema induced by carrageenan was associated with a significant increase in MPO activity, a marker of neutrophilic infiltration, from $3.21 \times 10^{2} \pm$ $0.0632 \times 10^{2}$ to $16.93 \times 10^{2} \pm 0.5216 \times 10^{2}(\mathrm{U} / \mathrm{mg}$ of tissue $)$
(Figure 5). In the group with edema induced by carrageenan pre-treated with EOHc $(100 \mathrm{mg} / \mathrm{kg})$ by the oral route, the carrageenan-induced increase of MPO activity was significantly decreased $(P<0.05)$ to about $40 \%$ of carrageenan control-induced MPO activity. Although undergoing a significant decline, MPO activity did not return to control levels, observed before carrageenan administration $(P<0.05$, Figure 5$)$.

\section{Discussion}

The major discovery of this investigation was that $\mathrm{EOHc}$ had an antiedematogenic effect in experimental models of acute edema. This EOHc effect was obtained with a great pharmacological efficacy and a conspicuously long duration. Since this is an accepted model of antiinflammatory activity, the data suggested that $\mathrm{EOHc}$ acted through an anti-inflammatory effect. This also showed, for the first time, that the effect of EOHc was very potent to prevent the formation of edema, but also has great efficacy in reversing the already installed edema.

Some EO of aromatic plants have antiedematogenic effects, such as C. zehntneri EO (21), Lavanda augustifolia 
A

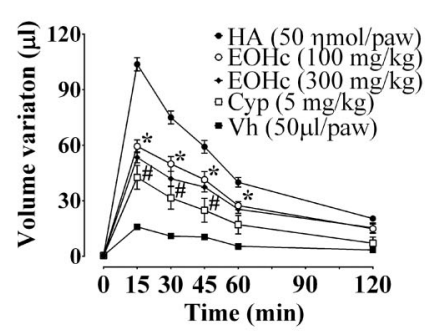

D

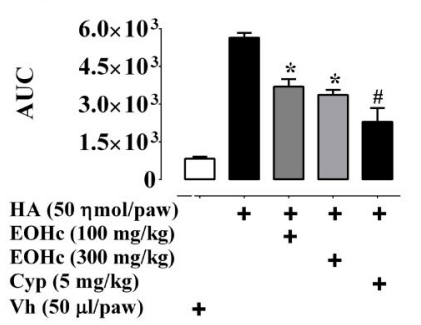

B

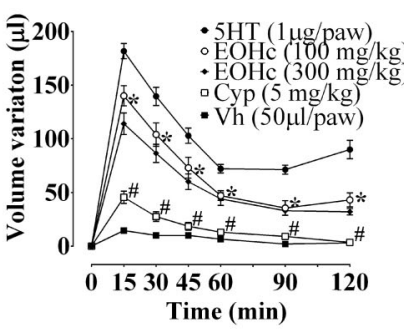

E

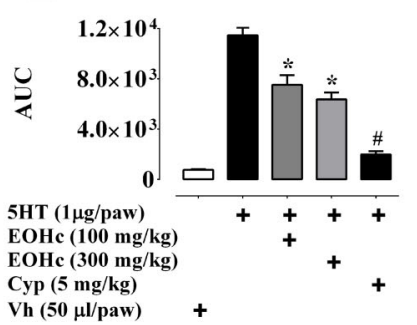

C

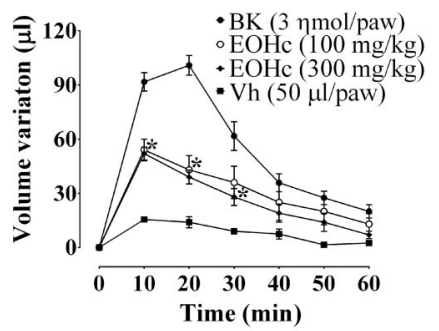

F

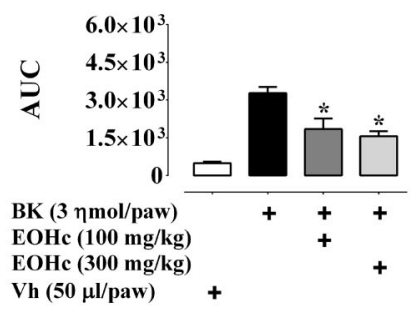

Figure 4. Effect of essential oil of Hyptis crenata (EOHc,100 and $300 \mathrm{mg} / \mathrm{kg}$, orally) on paw edema induced by histamine, serotonin, or bradykinin. A and D, Effect of EOHc and of cyproheptadine (Cyp, $5 \mathrm{mg} / \mathrm{kg}$ ) on the time course (15-120 min) of edema induced

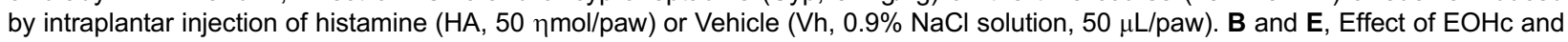
of Cyp $(5 \mathrm{mg} / \mathrm{kg}$ ) on the time course (15-120 min) of edema induced by intraplantar injection of serotonin (5HT, $1 \mu \mathrm{g} / \mathrm{paw})$ or Vehicle (Vh, $0.9 \% \mathrm{NaCl}$ solution, $50 \mu \mathrm{L} / \mathrm{paw})$. $\mathbf{C}$ and $\mathbf{F}$, Effect of EOHc on the time course (10-60 min) of edema induced by intraplantar injection of bradykinin (BK, $3 \eta \mathrm{mol} / \mathrm{paw}$ ) or Vehicle $(\mathrm{Vh}, 0.9 \% \mathrm{NaCl}$ solution, $50 \mu \mathrm{L} / \mathrm{paw})$. Data are reported as means $\pm \mathrm{SE}(\mathrm{n}=10)$. ${ }^{*} \mathrm{P}<0.05$ vs control, ${ }^{*} \mathrm{P}<0.05$ vs treated animals $(\mathrm{EOHc}, 100$ and $300 \mathrm{mg} / \mathrm{kg}$ ) (two-way ANOVA and one-way ANOVA followed by Bonferroni's test).

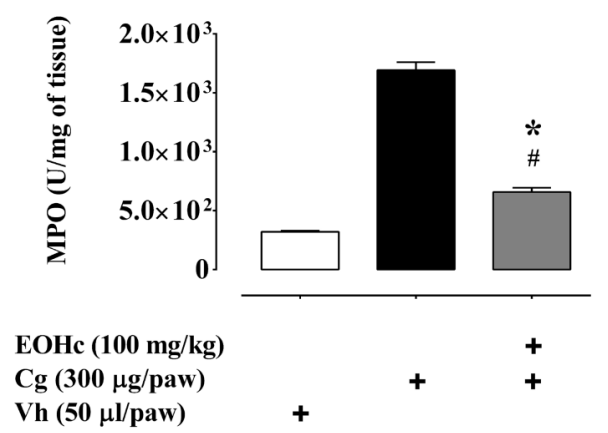

Figure 5. Effect of essential oil of Hyptis crenata (EOHc, $100 \mathrm{mg} /$ $\mathrm{kg}$, orally) on myeloperoxidase (MPO) levels. The MPO dosage was made in homogenized paw tissue after 3 hours of edema induced by intraplantar injection of carrageenan $(\mathrm{Cg}, 300 \mu \mathrm{g} / \mathrm{paw})$ or Vehicle (Vh, $0.9 \% \mathrm{NaCl}$ solution, $50 \mu \mathrm{L} /$ paw) and normalized by $\mathrm{mg}$ of tissue. Data are reported as means $\pm S E(n=6)$. ${ }^{*} P<0.05$ vs control, ${ }^{\#} \mathrm{P}<0.05$ vs vehicle (one-way ANOVA followed by Bonferroni's test).

EO (22), and Ocimum basilicum EO (23). However, it is worth mentioning that for $\mathrm{EOHc}$, the antiedematogenic effect occurs with very small doses $(10 \mathrm{mg} / \mathrm{kg})$, representing $<0.5 \%$ of the $\mathrm{LD}_{50}\left(\mathrm{LD}_{50}>2.0 \mathrm{~g} / \mathrm{kg}\right.$, orally $\left.(9)\right)$. Moreover, efficacy with such a small percentage of the $L_{50}$ was not observed for several other EOs, such as Lavandula augustifolia Mill EO (21) and Ocimum basilicum EO (22).

Previous studies with three species of the genus Hyptis, including $H$. crenata show that these plants have common constituents as alpha-pinene, 1,8-cineol, and beta-caryophyllene and point out that these species have important biological activities such as antioxidant and antimicrobial activity (24), in addition to low toxicity $(10,24)$. There are some works showing that monoterpene compounds present in EOHc have anti-inflammatory activity (25-27). The main components of $\mathrm{EOHc}$ are monoterpenoid and sesquiterpene compounds (28), such as camphor, alpha-pinene, 1.8-cineole, and beta-caryophyllene $(4,10,11,14)$. Therefore, EOHc, used traditionally for treatment of inflammatory diseases, also has antiinflammatory activity, as demonstrated here.

The induction of edema by phlogistic agents, such as dextran or carrageenan, is a classical model that allows evaluating substances with anti-inflammatory action. The $\mathrm{EOHc}$ showed an antiedematogenic effect in both models, which cause edema by distinct mechanisms. Dextran and carrageenan promote an increase in vascular permeability by different mechanisms. Therefore, analyzing this set of results, it is possible to suggest that $\mathrm{EOHc}$ possesses activity on vascular events of inflammation, possibly by inhibition of histamine and serotonin release by mast cells 
or by neutrophils, and/or by inhibition of action of these substances on receptors (29).

In the carrageenan-induced edema, it was evaluated if the time of administration of EOHc would influence the effect of the oil. Although it inhibited the edema at all times of administration, it was pharmacologically more potent when administered $60 \mathrm{~min}$ before induction (Figure $3 \mathrm{C}$ and D).

EOHc was more potent in inhibiting the carrageenaninduced edema than that induced by dextran. Oral pretreatment with 30,100 , or $300 \mathrm{mg} / \mathrm{kg}$ EOHc inhibited 60,75 , and $80 \%$ of carrageenan-induced and 40,50 , and $60 \%$ of the dextran-induced peak of edema, respectively. Dextran, a polysaccharide of high molecular weight, induces osmotic and acellular edema, mainly mediated by histamine and serotonin (5-hydroxytryptamine), consequent to the degranulation of mast cells residing in the endothelium of the microvessels $(30,31)$. The histamine and serotonin released, acting on their respective receptors $(H 1, H 2$, and $5 \mathrm{HT} 2)(31,32)$, lead to increased vascular permeability and fluid extravasation. On the other hand, carrageenan, a sulfated polysaccharide extracted from algae, induces an inflammatory response with different phases, with infiltrate containing large numbers of neutrophils and proteins (33-36). In the first phase, which occurs in the first 60 min after the injection of carrageenan, release of histamine and serotonin occurs. In the second phase (61-120 min), release of kinins predominantly occurs, such as bradykinin, and in the third phase (121-180 $\mathrm{min}$ ) the release of mainly prostaglandin occurs (33-35). EOHc inhibited the edema of cellular nature induced by carrageenan throughout the full time-course.

Since the inflammation induced by dextran involves the release of inflammatory mediators histamine and serotonin and carrageenan also involves bradykinins, the anti-inflammatory effect of $\mathrm{EOHc}$ implies at least a partial antagonistic effect of this EO to the edematogenic effect of these inflammatory mediators. This partial antagonistic effect of $\mathrm{EOHc}$ to the edematogenic activity of histamine, serotonin, and bradykinin was demonstrated here (Figure 4). Additionally, MPO increase, a parameter related to the inflammatory activity, was partially prevented by $\mathrm{EOHC}$ (Figure 5). EOHc inhibitory activity on the edema and MPO activity increase elicited by edematogenic stimuli demonstrated the true anti-inflammatory mechanism of this EO. Although the blockade by EOHc of the edema induced by histamine and serotonin was partial, at 100 and $300 \mathrm{mg} / \mathrm{kg}$, EOHc effect was similar to those of cyproheptadine and indomethacin (Figure 4), demonstrating the efficacy of this EO.

\section{References}

1. Uritu CM, Mihai CT, Stanciu GD, Dodi G, Alexa-Stratulat $T$, Luca $A$, et al. Medicinal plants of the family lamiaceae in
Additionally, carrageenan-induced paw edema lasts for $72 \mathrm{~h}$ and after that time only a hypernociceptive process remains (37). Although it was not the object of our investigation to evaluate the entire time course of carrageenan-induced paw edema, we observed that a single dose of $\mathrm{EOHC}(100 \mathrm{mg} / \mathrm{kg})$ was able to prevent edema increase up to $24 \mathrm{~h}$ of observation.

It was not the purpose of this work to fully investigate the mechanism of action for the anti-inflammatory effect of EOHc. However, based on the effects promoted by $\mathrm{EOHc}$ - i) inhibition of dextran-induced edema; ii) inhibition throughout the time course of carrageenaninduced edema; iii) inhibition of edema promoted by the inflammatory mediators histamine, serotonin, and bradykinin; and iv) inhibition of MPO activity - it is very likely that the antiedematogenic effect of EOHc was caused by antiinflammatory effect. The mechanism of this anti-inflammatory effect is, in part, likely to include the inhibition of increased vascular permeability, which occurs upon release of inflammatory mediators, like histamine, serotonin, cytokines, etc.

Other EOs, like Pterodon Polygalaeflorus (15), inhibit dextran-induced edema $(77.5 \%)$ and the first phase of carrageenan-induced edema $(76.98 \%)$. The authors suggested that this oil might be inhibiting the synthesis, release, and/or effects of histamine and serotonin (15).

In conclusion, we demonstrated that the EO of Hyptis crenata, a plant widely used in folk medicine, had antiedematogenic activity at very low doses compared to its $\mathrm{LD}_{50}$, and was likely to be of low toxicity. This EOHc effect, which is interpretable as anti-inflammatory activity due to its inhibitory effects on autacoids and on MPO activity, is consistent with its anti-inflammatory use in folk medicine. The oil showed a potent effect in both edema prevention and reversal of the edema already installed. EOHc efficacy at doses likely to be of low toxicity in humans suggested that this oil has potential for therapeutic use and also that the popular medicinal use of the plant could have a scientific foundation.

\section{Acknowledgments}

This research was supported by the Conselho Nacional de Pesquisa e Desenvolvimento Tecnológico (CNPq), Coordenação de Aperfeiçoamento de Pessoal de Nível Superior (CAPES), Fundação de Amparo ao Desenvolvimento Científico e Tecnológico do Estado do Ceará (FUNCAP), Financiadora de Estudos e Projetos (FINEP), and UNICHRISTUS.

pain therapy: a review. Pain Res Manag 2018; 2018 : 7801543, doi: 10.1155/2018/7801543. 
2. Carović-StanKo K, PeteK M, Martina G, Pintar J, Bedeković $D$, Ćustić $M H$, et al. Medicinal plants of the family Lamiaceaeas functional foods - a review. Czech $J$ Food Sci 2016; 34: 377-390, doi: 10.17221/504/2015-CJFS.

3. Pinheiro MA, Magalhaes RM, Torres DM, Cavalcante RC, Mota FSX, Coelho EMAO, et al. Gastroprotective effect of alpha-pinene and its correlation with antiulcerogenic activity of essential oils obtained from Hyptis species. Pharmacogn Mag 2015; 11: 123-130, doi: 10.4103/0973-1296.149725.

4. Zoghbi MDGB, Andrade EHA, da Silva MHL, Maia JGS, Luz AIR, da Silva JD. Chemical variation in the essential oils of Hyptis crenata Pohl ex Benth. Flavour Frag J 2002; 17: 5-8, doi: 10.1002/ffj.1031.

5. Rebelo MM, da Silva JKR, Andrade EHA, Maia JGS. Antioxidant capacity and biological activity of essential oil and methanol extract of Hyptis crenata Pohl ex Benth. Rev Bras Farmacogn 2009; 19: 230-235, doi: 10.1590/S0102695X2009000200009.

6. de Jesus NZT, Lima JCDS, da Silva RM, Espinosa MM, Martins DTDO. Levantamento etnobotânico de plantas popularmente utilizadas como antiúlceras e antiinflamatórias pela comunidade de Pirizal, Nossa Senhora do LivramentoMT, Brasil [in Portuguese]. Rev Bras Farmacogn 2009; 19: 130-139, doi: 10.1590/S0102-695X2009000100023.

7. Falcão D, Menezes F. Revisão etnofarmacológica, farmacológica e química do gênero Hyptis [in Portuguese]. Rev Bras Farmacogn 2003; 84: 69-74.

8. Diniz LRL, Vieira CFX, dos Santos EC, Lima GC, Aragão $\mathrm{KKV}$, Vasconcelos RP, et al. Gastroprotective effects of the essential oil of Hyptis crenata Pohl ex Benth on gastric ulcer models. J Ethnopharmacol 2013; 149: 694-700, doi: 10.1016/ j.jep.2013.07.026.

9. Di Stasi LC, Oliveira GP, Carvalhaes MA, Queiroz-Junior M, Tien OS, Kakinami SH, et al. Medicinal plants popularly used in the Brazilian Tropical Atlantic Forest. Fitoterapia 2002; 73: 69-91, doi: 10.1016/S0367-326X(01)00362-8.

10. Alves-Soares R, Gomes-Vasconcelos YA, Oliveira KA, Diniz LRL, Silva-Alves KS, Ferreira-da-Silva FW, et al. Evaluation of oral acute toxicity of essential oil of Hyptis crenata in mice. An Acad Cear Ciênc 2018; 2: 126-132. < http://www.aceci. com.br/2019/03/12/anais-da-academia-cearense-de-cienciasvol-02-n-02/>. Accessed November 26, 2020.

11. Scramin S, Saito ML, Pott A, Marques MOM. Volatile constituents of Hyptis crenata Pohl (Labiatae) native in Brazilian pantanal. J Essent Oil Res 2000; 12: 99-101, doi: 10.1080/10412905.2000.9712052.

12. Violante IMP, Hamerski L, Garcez WS, Batista AL, Chang MR, Pott VJ, et al. Antimicrobial activity of some medicinal plants from the cerrado of the central-western region of Brazil. Braz J Microbiol 2012; 43: 1302-1308, doi: 10.1590/ S1517-83822012000400009.

13. Violante IMP, Garcez WS, da Silva-Barbosa C, Garcez FR. Chemical composition and biological activities of essential oil from Hyptis crenata growing in the Brazilian cerrado. Nat Prod Commun 2012; 7: 1387-1389, doi: 10.1177/1934578 $\mathrm{X} 1200701037$.

14. Lima GC, Vasconcelos YAG, de Santana-Souza MT, Oliveira AS, Bomfim RR, de Albuquerque-Júnior RLC, et al. Hepatoprotective effect of essential oils from Hyptis crenata in sepsis-induced liver dysfunction. $J$ Med Food 2018; 21: 709-715, doi: 10.1089/jmf.2017.0125.
15. Coelho-de-Souza AN, dos-Santos CF, Lopes-Filho LN, Holanda FR, Oliveira AC, Gomes-Vasconcelos YA, et al. Essential oil of Pterodon polygalaeflorus Benth attenuates nociception in mice. Braz J Med Biol Res 2018; 51: e7356, doi: 10.1590/1414-431x20187356.

16. Abdon APV, Leal-Cardoso JH, Coelho-de-Souza AN, Morais SM, Santos CF. Antinociceptive effects of the essential oil of Croton nepetaefolius on mice. Braz J Med Biol Res 2002; 35:1215-1219, doi: 10.1590/S0100-879X2002001000015.

17. Araújo PF, Coelho-de-Souza AN, Morais SM, Santos CF, Leal-Cardoso $\mathrm{JH}$. Antinociceptive effects of the essential oil of Alpinia zerumbet on mice. Phytomedicine 2005; 12 : 482-486, doi: 10.1016/j.phymed.2004.04.006.

18. Sousa PJC, Linard CFBM, Azevedo-Batista D, Oliveira AC, Coelho-de-Souza AN, Leal-Cardoso JH. Antinociceptive effects of the essential oil of Mentha $x$ villosa leaf and its major constituent piperitenone oxide in mice. Braz $J$ Med Biol Res 2009; 42: 655-659, doi: 10.1590/S0100-879X200 9000700010

19. Perazzo FF, Lima LM, Padilha MDM, Rocha LM, Sousa PJ, Carvalho JCT. Anti-inflammatory and analgesic activities of Hypericum brasiliense (Willd) standardized extract. Rev Bras Farmacogn 2008; 18: 320-325.

20. Rao TS, Currie JL; Shaffer AL, Isakson PC. Comparative evaluation of arachidonic acid (AA)-and tetradecanoylphorbol acetate (TPA)-induced dermal inflammation. Inflammation 1993; 17: 723-741, doi: 10.1007/BF00920477.

21. Oliveira AC, Leal-Cardoso JH, Santos CF, Morais SM, Coelho-de-Souza AN. Antinociceptive effects of the essential oil of Croton zehntneri in mice. Braz J Med Biol Res 2001; 34: 1471-1474, doi: 10.1590/S0100-879X2001001100016.

22. da Silva GL, Luft C, Lunardelli A, Amaral RH, Melo DA, Donadio MV, et al. Antioxidant, analgesic and anti-inflammatory effects of lavender essential oil. An Acad Bras Ciênc 2015; 87: 1397-1408.

23. Rodrigues LB, Martins AOBPB, Cesário FRAS, Castro FF, de Albuquerque TR, Fernandes MNM, et al. Anti-inflammatory and antiedematogenic activity of the Ocimum basilicum essential oil and its main compound estragole: in vivo mouse models. Chem Biol Interact 2016; 257: 14-25, doi: 10.1016/j.cbi.2016.07.026.

24. Xu DH, Huang YS, Jiang DQ, Yuan K. The essential oils chemical compositions and antimicrobial, antioxidant activities and toxicity of three Hyptis species. Pharm Biol 2013; 51: 1125-1130, doi: 10.3109/13880209.2013.781195.

25. Silva J, Abebe W, Sousa SM, Duarte VG, Machado MIL, Matos FJA. Analgesic and anti-inflammatory effects of essential oils of Eucalyptus. J Ethnopharmacol 2003; 89: 277-283, doi: 10.1016/j.jep.2003.09.007.

26. las Heras B, Rodriguez B, Bosca L, Villar AM. Terpenoids: sources, structure elucidation and therapeutic potential in inflammation. Curr Top Med Chem 2003; 3: 171-185, doi: 10.2174/1568026033392462.

27. Santos FA, Silva RM, Campos AR, de Araujo RP, Júnior RL, Rao VSN. 1,8-cineole (eucalyptol), a monoterpene oxide attenuates the colonic damage in rats on acute TNBS-colitis. Food Chem Toxicol 2004; 42: 579-584, doi: 10.1016/j.fct. 2003.11.001.

28. McNeil M, Facey P, Porter R. Essential oils from the Hyptis genus-a review (1909-2009). Nat Prod Commun 2011; 6: 1775-1796. 
29. Roome T, Dar A, Ali S, Naqvi S, Choudhary MI. A study on antioxidant, free radical scavenging, anti-inflammatory and hepatoprotective actions of Aegiceras corniculatum (stem) extracts. J Ethnopharmacol 2008; 118: 514-521, doi: 10.1016/j.jep.2008.05.021.

30. Vysakh A, Jayesh K, Helen LR, Jyothis M, Latha MS. Acute oral toxicity and anti-inflammatory evaluation of methanolic extract of rotula aquatica roots in Wistar rats. $J$ Ayurveda Integr Med 2018; 11: 45-52, doi: 10.1016/j.jaim.2017.09. 007.

31. Lo TN, Almeida AP, Beaven MA. Dextran and carrageenan evoke different inflammatory responses in rat with respect to composition of infiltrates and effect of indomethacin. J Pharmacol Exp Ther 1982; 221: 261-267.

32. Katz LB, Theobald HM, Bookstaff RC, Peterson RE. Characterization of the enhanced paw edema response to carrageenan and dextran in 2,3,7,8-tetrachlorodibenzop-dioxin-treated rats. J Pharmacol Exp Ther 1984; 230: 670-677.
33. Di Rosa M, Giroud JP, Willoughby DA. Studies on the mediators of the acute inflammatory response induced in rats in different sites by carrageenan and turpentine. J Pathol 1971; 104: 15-29, doi: 10.1002/path.1711040103.

34. Willis AL. Parallel assay of prostaglandin-like activity in rat inflammatory exudate by means of cascade superfusion. J Pharm Pharmac 1969; 21: 126-128, doi: 10.1111/j.20427158.1969.tb08213.x.

35. Willis AL. Release of histamine, kinin and prostaglandin during carrageenan induced inflammation in the rat.In:Wills AL, Montagazza P, Horton EW, Prostaglandins, Peptides and Amins, London: Academic Press; 1969. p 31-38.

36. Morris CJ. Carrageenan-induced paw edema in the rat and mouse. Methods Mol Biol 2003; 225: 115-121.

37. Aley KO, Messing RO, Mochly-Rosen D, Levine JD. Chronic hypersensitivity for inflammatory nociceptor sensitization mediated by the epsilon isozyme of protein kinase C. J Neurosci 2000; 20: 4680-4685, doi: 10.1523/JNEURO SCI.20-12-04680.2000. 